International Journal of Linguistics, Literature and Translation

ISSN: 2617-0299 (Online); ISSN: 2708-0099 (Print)

DOI: 10.32996/ijltt

Journal Homepage: www.al-kindipublisher.com/index.php/ijltt

\title{
Smartphones as a Tool for Expediting English Vocabulary Learning: Teachers' Perceptions of Benefits and Drawbacks
}

\author{
Rami A. Sa'di ${ }^{1}$ (D) $\triangle$, Talha A. Sharadgah ${ }^{2}$ (D) and Maha Yaseen ${ }^{3}$ (D) \\ ${ }^{1}$ Assistant Professor of Linguistics, Prince Sattam bin Abdulaziz University, P.O.Box: 1866 AlKharj 11942, Saudi Arabia \\ ${ }^{2}$ Assistant Professor of TESOL, Prince Sattam bin Abdulaziz University, P.O.Box: 1866 AlKharj 11942, Saudi Arabia \\ ${ }^{3}$ Assistant Professor of linguistics, Al-Ahliyya Amman University, Amman, Jordan
}

$\triangle$ Corresponding Author: Rami A. Sa'di, E-mail: r.alsadi@psau.edu.sa

\section{ARTICLE INFORMATION}

Received: March 08, 2021

Accepted: April 15, 2021

Volume: 4

Issue: 4

DOI: $10.32996 /$ ijllt.2021.4.4.13

\section{KEYWORDS}

Benefits and drawbacks, English vocabulary learning, smartphones, teachers' perceptions

\section{ABSTRACT}

This study surveyed teachers' perceptions of the efficiency of utilizing smartphones as a tool for helping EFL students ameliorate their English vocabulary learning. A 27-item questionnaire was administered to 120 teachers working at various state and private secondary schools in Saudi Arabia. Findings revealed that the great majority of teachers (84\%) considered smartphones an effective tool for teaching vocabulary. The current study also showed that teaching experience had statistically significant effects on teachers' perceptions in favour of teachers with a moderate number of years of experience (more than 5 and less than 10 years). However, there were no statistically significant differences on teachers' perceptions yielded by the gender variable. Furthermore, the current study showed that ease of use, the ability to engage students anywhere and anytime, learning through game applications, and offering a great deal of exposure to foreign language received the highest rate of agreement. Additionally, teachers believed that several drawbacks might impact the integration of smartphones into the classroom, including low quality of existing apps, lack of training on smartphones for academic purposes and the disruption and distraction they cause.

\section{Introduction}

It is axiomatic that vocabulary learning is central to the development of students' English language skills because vocabulary learning is inseparable from learning the four language skills. Therefore, building excellent vocabulary knowledge plays an essential part in "learning to communicate effectively while listening, speaking, reading, and writing" (Rochman, 2010). Wilkins (1972) believes that "without grammar very little can be conveyed [and] without vocabulary nothing can be conveyed." By contrast, poor vocabulary knowledge contributes to poor communication skills (Goz \& Ozcan 2017). According to Behbahani (2016), "if students acquire a deep and rich vocabulary knowledge base, they can convey their message more efficiently." (p. 646)

In educational contexts, unprecedented advancements in technology have changed how teachers teach, and students learn. Teachers employ technology for a variety of educational tasks, including instruction, along with administration purposes, while students use technology to do classwork. In this digital age, teaching cannot be imagined without the application of technology. The invention of smartphones is one of the biggest feats in technological upheavals, which has significantly revolutionized the way teachers and students communicate and share information with each other. Smartphones are small in size, easy to carry, easy to use (Reddy, Reddy, Sharma, Reddy \& Khan, 2016); they provide access to the Internet, provide the possibility to download applications, allow students the flexibility to access activities anywhere and anytime (Yaman, Şenel \& Yeşilel, 2015); they allow students to communicate with their teachers and peers in real-time (Lee, 2014, p. 111), and much more.

\section{K C AL-KINDI CENTER \\ $\mathbf{R}$ D FOR RESEARCH AND DEVELOPMENT}

Your gateway to world-class research

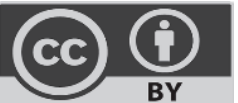

Published by Al-Kindi Center for Research and Development, London, United Kingdom. Copyright (c) the author(s). This open access article is distributed under a Creative Commons Attribution (CC-BY) 4.0 license 
EFL Teachers can exploit the advantages of smartphones in order to expedite their students' amelioration of their lexical repertoire and to help them stay engaged in learning anywhere and anytime. Incorporating smartphones into EFL contexts can make vocabulary learning more attractive and motivating (Agca \& Özdemir, 2013). Also, utilizing smartphone apps for vocabulary learning encourages self-directed learning and plays a significant role in improving and enhancing vocabulary knowledge (Wang $\&$ Shih, 2015). Teachers can employ smartphones "to create a new and exciting learning experience in the classroom" (Medzini, Meishar-Tal, \& Sneh, 2015).

This study focuses on EFL teachers' perceptions of the efficiency of utilizing smartphones as a device for expediting English vocabulary learning. The researchers created a 27-item questionnaire that was administered to 120 schoolteachers working in 47 state and private schools in Saudi Arabia. 73 teachers were male, and 47 were female. The teachers were asked to respond to 'fivepoint Likert scale' questions. The responses were then analysed to find out the tecahers' perceptions of smartphones as a potential tool for helping EFL learners ameliorate their English vocabular learning and their lexical awareness. In the process of data collection, a number of limitations had to be grappled with. For one thing, some of the schools approached did not respond, and the authors had to seek alternatives. Also, some of the teachers who were given a copy of the survey did not return them, and so the authors had to seek alternatives too. This paper poses research questions at the outset, and through the responses to the questionnaire, it attempts to determine the teachers' perceptions of smartphones as a tool for ameliorating vocabulary learning. The findings of the study, as shown in the Findings section, showed that 16 advantages and 11 drawbacks for the use of smartphones were detected according to teachers' perceptions.

The study will explore the benefits and drawbacks of utilizing smartphones as a vocabulary learning tool. Specifically, three questions will be raised in this study:

RQ1: Are there any statistically significant differences in teachers' perceptions of utilizing the smartphone as a vocabulary learning tool that is attributed to gender and teaching experience?

RQ2: What are the perceived benefits of utilizing the smartphone as a vocabulary learning tool as identified by English teachers?

RQ3: What are the perceived drawbacks of utilizing the smartphone as a vocabulary learning tool as identified by English teachers?

Whilst a growing body of theoretical and empirical work investigates the utilization of smartphones in English vocabulary learning, this study attempts to further elucidate this subject among Saudi EFL teachers. The findings of this study are expected to benefit teachers and students in a plurality of ways. First, this study is useful for EFL students as it provides them with ways through which they can increase their vocabulary knowledge. Further, the study is significant to EFL teachers as it directs their attention towards smartphones as a valuable tool for teaching vocabulary. Finally, teachers can gain insight on how to develop different and often innovative ways to teach vocabulary utilizing smartphones as an unconventional tool for learning.

\section{Literature Review}

Prior studies revealed the effectiveness of smartphones as a device for improving EFL students' English vocabulary learning (Turgay \& Gurluyer, 2017; Jafari \& Chalak, 2016; Lakshmi \& Nageswari, 2015; Yaman, Şenel \& Yeşilel, 2015; Lee, 2014; Nikoopour \& Kazemi, 2014; Hayati, Jalilifar \& Mashhadi, 2013; Azabdaftari \& Mozaheb, 2012; Lu, 2008). Smartphones can positively increase students' engagement (Wang \& Shih, 2015; Woodcock, Middleton, \& Nortcliffe, 2012), motivation (Afzali, Shabani, Basir, \& Ramazani, 2017; O'bannon \& Thomas, 2014), productivity (O'bannon \& Thomas, 2014), communication skills (Lakshmi \& Nageswari, 2015), and commitment to the tasks (Levy \& Kennedy, 2005).

Smartphones are small-size "mini-computer devices" (Zhu, Hines, Burton, \& Liao, 2014), which offer abundant practical uses that are beneficial to teachers and students. Portability and easy access to information through smartphones enable students to be exposed to foreign language resources at school, home, library, and almost anywhere and at any time (Rico, Naranjo, MDelicado, Plaza, \& Domínguez, 2014). Storing information to be used later is another important feature of smartphones (Mlotshwa \& Giannakopoulos, 2015). The ability to retrieve information when inside or outside school has proven itself as the most efficient and rapid-achieving method of learning, teaching, or even revising the subject before entering the exam (Pereira, \& Cadavieco, 2016). Also, a wide variety of smartphone applications are now designed and developed specifically to meet "the needs of teachers and students" (Lo, 2013). Some of these applications are free, and some could be purchased online where teachers and students can choose the applications as appropriate to the educational situation (Muhammed, 2014).

Smartphone features can be used in a multiplicity of ways to facilitate teaching and learning vocabulary. Students can take the advantage of using dictionary applications in their smartphones to look up the meanings of new words and to check out the pronunciation and spelling of unfamiliar words (Turgay and Gurluyer, 2017). Smartphones also allow teachers to create 
vocabulary activities that can provide opportunities for students to practise foreign language words meaningfully and creatively (Patriana Ch, Irawan, Tampubolon, \& Pane, 2015). Additionally, smartphones can provide students and teachers with new techniques for vocabulary learning through existing game applications (Alzahrani, 2016). Students can also use their smartphones to download apps, videos, audio files, and text with the potential to enhance vocabulary learning in and out of the classroom (Molina, Redondo, Lacave, \& Ortega, 2014).

Furthermore, smartphones allow students to send and receive free vocabulary messages to one other online. Most of the studies that explored the impact of short messages on vocabulary learning reported positive results (Bensalem, 2018; Wang \& Shih, 2015; Wu, 2015; Lu, 2008). Likewise, smartphones encourage EFL students to learn English vocabulary using social media (Mahajaroenkul, 2017). As a matter of fact, these social media sites potentially have a primary role in the development of English language learning because they resemble real learning environments (Thorne, Black \& Sykes, 2009).

\subsection{Benefits of the smartphone as a vocabulary learning tool}

Smartphones are increasingly recognized for their ability to allow students and teachers the flexibility of learning vocabulary anywhere and at any time (Keengwe \& Bhargava, 2014). Smartphones have a variety of features that enable users to create educational contents (Hartnell-Young \& Vetere, 2008). They have the "ability to address the different learning styles of the learners": visual, auditory, and kinaesthetic (Keengwe \& Bhargava, 2014). Using these smart devices helps to create a studentcentred learning environment (Beck \& Eno, 2012). They can provide students with educational materials "in different versatile formats like podcasts, videos, or audio recordings etc." (Keengwe \& Bhargava, 2014, p. 744). Smartphones allow students to benefit from authentic learning materials (Popescu, 2011).

One of the revolutionary features of the smartphone is that it provides students with the ability to connect to the Internet and use digital content and services to help improve their English vocabulary learning (Al-Otaibi, AlAmer, \& Al-Khalifa, 2016; Wang, 2015). This technology also encourages self-learning and self-assessment (Al-Said, 2015) as well as collaboration among students (Norris, Hossain, \& Soloway, 2011).

\subsection{Drawbacks of utilizing smartphones as a vocabulary learning tool}

Although there are numerous advantages to using smartphones as instructional tools, considerable barriers were identified in the literature, including the disruption they cause to social life (Thomas, O'Bannon, \& Britt, 2014; Shelton, Elliott, Lynn, \& Exner, 2011), the problems of synchronization with alternative resources (Dimond, Bullock, Lovatt, \& Stacey, 2016), cheating (Thomas, O'Bannon, \& Britt, 2014), and cyberbullying (Kyriacou, \& Zuin, 2016; McNeill, Rice, \& Wright, 2016).

A number of regular barriers also obstruct the utilization of smartphones as teaching and learning tools, including the cost of the devices (Plackett, Thomas, \& Thomas, 2017; Dimond, Bullock, Lovatt, \& Stacey 2016), battery life limitations (Al-Said, 2015), the small-size screen (Ghosh, Jha, \& Malakar, 2016), limited memory (Yus, Bobed, Esteban, Bobillo, \& Mena, 2013), fear of change (Thomas, O'Bannon, \& Britt, 2014), poor accessibility (Plackett, Thomas, \& Thomas, 2017), and smartphone's small keyboard (Wang \& Shen, 2012). The researchers, however, believe that it is going to be only a matter of time before most of these drawbacks are resolved by the manufacturing companies.

\section{Method}

\subsection{Participants}

The sample of this study was randomly selected from amongst English language teachers working at state and private schools in Saudi Arabia. The participants were selected from 47 schools at the beginning of the first semester of 2019/2020. A total of 120 participants responded to the questionnaire of this study. The tecahers' ages ranged between 24 and 61 . Among these participants, 60\% (73) were males, and 40\% (47) were females. All participants were native speakers of Arabic who were teaching English as a foreign language (EFL). $84 \%$ of the participants indicated that they had previously, by one way or another, used smartphones to communicate with their students. The majority of the participants were familiar with smartphones and had considerable experience using them.

\subsection{Instruments}

Subsequent to a considerable review of relevant research studies, the researchers devised a 27 -item questionnaire on a voluntary basis. The questionnaire used a 'five-point Likert scale' (ranging from $1=$ Strongly Disagree (SD); to $5=$ Strongly Agree (SA) to elicit teachers' perceptions of utilizing smartphones as a vocabulary learning tool. The statements of the questionnaire were grouped into two categories: 16 statements dealt with the benefits of smartphones as a vocabulary learning tool, whereas 11 statements aimed to elicit from the teachers possible perceived drawbacks in using smartphones as a vocabulary learning tool. The questionnaire was distributed in hard copy in person so that any misunderstanding could be avoided. 
To gather the data needed for this paper, the questionnaire was administered to English language teachers in both private and state secondary schools in Saudi Arabia. The questionnaire contained three sections that aimed to elicit teachers' perceptions of using smartphones as a device for teaching vocabulary. The first section was intended to collect 'demographic information', namely gender and teaching experience. The second section was designed to investigate teachers' perceptions of the benefits of using smartphones as a device for teaching vocabulary. The third part was intended to elicit the main perceived drawbacks to using smartphones for teaching vocabulary.

\subsection{Procedure}

To ensure the content validity, the instrument was given to a panel of specialists in the field, experienced teachers in EFL teaching. The teachers were asked to evaluate the questionnaire items in terms of appropriateness, comprehensibility, clarity and overall quality for the purpose of the study. In accordance with the experts' comments and suggestions, the questionnaire was modified before it was put into practice. To achieve the reliability of the instrument, a pilot study was administered to 34 teachers that were not selected for the actual study. Cronbach Alpha reliability of the questionnaire items was found to be (0.88). This value gives an indication of high reliability.

For the implementation of the questionnaire, the researchers prepared a list of all secondary schools in four cities in Saudi Arabia. The researchers then recorded the names of the schools on pieces of paper, folded them and placed them in a box, and then picked the required number of schools randomly. After that, the researchers went to the specific schools and met the school principals and the English teachers of the secondary level. After explaining the study, the researchers asked the teachers to voluntarily participate in filling out the questionnaire. When the researchers were unable to meet teachers at any particular school or if teachers refused to participate, the researchers picked new names of schools from the box at random.

The researchers developed a convenient schedule to visit the selected schools. The data collection started on August 10 and ended on September 8, 2019. No missing data occurred in the completed copies of the questionnaires, as the researchers checked for unanswered items after each participant had completed filling out the questionnaire. Nine participants missed one or two items, and the researchers asked them to fill them in. All teachers had no problems understanding the items or the instructions provided that were necessary for the questionnaire to be completed properly.

\subsection{Data Analysis}

For this study, the questionnaire was divided into three sections based on the questions of the study. The responses of the participants to the questionnaire items were statistically analysed using the "Statistical Package for Social Science (SPSS)". Statistical techniques included analysis of means (M), standard deviations (SD), frequencies, and percentages in order to calculate the data collected about teachers' perceptions of the efficiency of utilizing smartphones as a vocabulary learning tool. Additionally, one-way ANOVA and $t$-test were utilized to evaluate the statistical significance of the data. Values of $p \leq 0.05$ were considered statistically significant.

\section{Findings}

\subsection{Demographic Information}

The first part of the questionnaire collected demographic information about the participants. The two demographic components included in this study were gender and teaching experience.

\subsubsection{Gender}

As for gender of the participants, out of the 120 teachers, there were 73 (63\%) males and 47 (57\%) females as shown in Table 1.

Table (1): Frequency, mean, Standard Deviation, and $t$-test Results According to Gender

\begin{tabular}{lccccc}
\hline Gender & Frequency & M & SD & t & df \\
\hline Male & 73 & 62.70 & 33.77 & .862 & 118 \\
Female & 47 & 57.09 & 36.39 & & \\
Total & 120 & & & & \\
\hline
\end{tabular}

Table 1 also shows a little variation in mean scores of male $(M=62.70, \mathrm{SD}=33.77)$ and female $(M=57.09, \mathrm{SD}=36.39)$ teachers. The results of the $t$-test show that there is no statistically significant difference based on gender, $t(118)=.862, p=.390$. Roughly speaking, both males and females use smartphones as a tool for teaching to a similar extent. 


\subsubsection{Teaching Experience}

The teachers were also asked to state the number of years of experience they had in teaching. Of the 120 participants, 42 (35\%) had 5 years or less of experience, 57 (47.5\%) had more than 5 and less than 10 years of experience, and 21 (17.5\%) had been in the teaching profession for more than 10 years.

Results show differences in mean scores of teachers according to teaching experience. There was variation in the mean scores of teachers with 5 years or less of teaching experience $(M=50.29, \mathrm{SD}=29.71)$, more than 5 and less than 10 years of experience ( $M$ $=67.53, \mathrm{SD}=35.99)$, and more than 10 years of experience $(M=61.86, \mathrm{SD}=37.41)$. One-way ANOVA was conducted to find out whether the variations that existed between mean scores were statistically significant, as displayed in Table 2:

Table (2): One-way ANOVA Result According to Teaching Experience

\begin{tabular}{lcccc}
\hline & Sum of Squares & df & Mean Square & F \\
\hline Between Groups & 7234.647 & 2 & 3617.323 & 3.095 \\
Within Groups & 136755.353 & 117 & 1168.849 & \\
Total & 143990.000 & 119 & & \\
\hline
\end{tabular}

Table 2 above shows that there were statistically significant differences according to teaching experience in favour of the (more than 5 and less than 10 years of experience) category, $F(2,117)=3.095, p=.049$.

\subsection{Benefits of using the smartphone as a vocabulary learning tool}

Teachers were requested to recognize the benefits of smartphones that are perceived to be useful for ameliorating vocabulary learning. The teachers expressed to which extent they agreed or disagreed with 16 statements describing the benefits of smartphones as a vocabulary learning tool. The primary benefits identified as most useful were ease of use of the smartphone ( $M$ $=3.89, \mathrm{SD}=1.22)$, the ability to engage students anywhere and anytime $(M=3.86, \mathrm{SD}=1.117)$, learning through game apps $(M=$ $3.85, \mathrm{SD}=1.221)$, and offering students a great deal of exposure to foreign language vocabulary $(M=3.85, \mathrm{SD}=1.026)$. By contrast, the benefits they classified to be the least beneficial were the ability to 'personalize instruction' (Steel, 2012) $(M=3.19$, $\mathrm{SD}=1.416)$, the possibility to create student-centred learning opportunities $(M=3.28, \mathrm{SD}=1.490)$, and the ability to use existing instructional applications designed specifically to help students build vocabulary $(M=3.36, \mathrm{SD}=1.477)$.

\subsection{Drawbacks of using the smartphone as a vocabulary learning tool}

The participants also indicated to which extent they agreed or disagreed with 11 statements about drawbacks that might adversely impact the utilization of smartphones as a vocabulary learning tool. The responses to the questionnaire demonstrated that teachers considered all likely drawbacks to be obstacles; however, they were more attentive to some drawbacks than to others. The primary drawbacks specified were poorly designed vocabulary applications $(M=3.57, \mathrm{SD}=1.333)$, lack of training on smartphones for academic purposes $(M=3.45, S D=1.365)$, and smartphones having the potential to disrupt the instruction and distract students $(M=3.41, S D=1.273)$. By contrast, they were least concerned about using smartphones for cheating during educational events $(M=2.62, S D=1.391)$, the small-size screen $(M=3.16, S D=1.250)$, and the small-size keyboard $(M=3.16$, SD $=1.250)$.

\section{Discussion}

This study was implemented to investigate teachers' perception toward using smartphones as a tool for expediting EFL students' vocabulary knowledge. The study also examined the impact of 'gender' and 'teaching experience' on teachers' perceptions. Additionally, the study attempted to fathom benefits and drawbacks of utilizing smartphones as a tool for ameliorating vocabulary learning.

Results of the study revealed that teachers' perceptions of smartphones as a tool for vocabulary teaching were not influenced by gender. This finding is compatible with most of prior studies, which have found no significant differences between males and females in relation to the implementation of technology in education (Alkhoudary, 2018; Maican \& Cocoradă, 2017; Aljasir, Woodcock, \& Harrison, 2013). Results also indicated that teachers' perceptions of smartphones as a tool for expediting English vocabulary learning significantly differed by years of teaching experience, in favour of the 'more than five and less than ten years of experience' group. This means that teachers with relatively moderate teaching experience find smartphones more effective as a tool for teaching than teachers with low and teachers with high teaching experience. To some extent, this is compatible with the findings of Bauer (2002) that those "old teachers with more experience are less likely to use technology" in teaching. This chariness of the older teachers of incorporating technology into their teaching is ascribable to several reasons, including older teachers having higher levels of technology anxiety (Rahimi \& Yadollahi, 2011), lack of knowledge and training on how to 
integrate this technology (Dunn \& Ridgway, 1991). Similarly, those who have little teaching experience are less likely to utilize technology with students; "perhaps they need to first master the routines of teaching before initiating innovative practices" (Ravitz, Wong, \& Becker, 1999). Therefore, teachers with the moderate number of years of experience may be more adapted to the use of smartphones in teaching.

According to the responses of the 120 participants, four of sixteen benefits had the highest level of rating. The first highest rated benefit was 'ease of use of the smartphone.' $35.7 \%$ of teachers agreed and $40.0 \%$ strongly agreed with this benefit. Barhoumi (2015) found that ease of use is a significant factor that influenced students' general use of mobile devices. Similarly, Goh (2015) stressed that the ease of use of the smartphone makes students more confident than does the complexity of computers that may lead to the reluctance to use, or a total rejection of, e-learning. The second highest-rated benefit was 'the ability to engage students anywhere and anytime.' $45.0 \% \%$ of teachers agreed and $30.0 \%$ strongly agreed with this feature. The result of this point approves Hu's (2013) survey in which the researcher examined the effect of delivering new vocabulary items through text messages on the overall process of EFL vocabulary learning. Results showed that smartphones offer an alternative source for students to learn vocabulary anytime and anywhere. These findings corroborate Steel's (2012) findings that mobile phones " offer a wide range of learning tools they can be downloaded to their mobile devices and used productively at opportune times in a variety of settings and on-the-go" (p. 1) According to Steel (2012), smartphones are a more practical help for learning because they extend the scope of learning to arenas outside the classroom. This is especially useful when the classroom time is limited.

Additionally, two advantages got the third-highest rating by the participants. The first advantage is 'the ability to learn vocabulary through game applications.' $71.6 \%$ of teachers strongly agreed or agreed with the benefit. When using smartphones, teachers can incorporate vocabulary learning apps that are in the kind of games into the classroom to reinforce students' learning. Uberman (1998) indicated that using games in language learning could lower students' anxiety, increase their motivation, and involve shy students. Comparably, Sandberg, Maris and Hoogendoorn (2014) examined the effect of engaging students in English vocabulary learning using a smartphone game-based app. They found that teachers value the active role smartphones play when integrating entertainment into the learning process. The second advantage that received high rating was that 'smartphones offer students a great deal of exposure to foreign language words.' $64.1 \%$ of the participants agreed or strongly agreed with this feature. Several studies have demonstrated that smartphone-based learning holds great potential in offering students a great deal of exposure to foreign language because of its convenient access (Im, 2014).

According to the responses, three benefits received the lowest proportion of rating by the participants. These benefits were believed to be the least useful for vocabulary learning. Only $45 \%$ of the participants strongly agreed or agreed on "smartphones ability to 'personalize instruction' (Steel, 2012)." According to Ehrcke (2013), personalized instruction requires many resources, such as "smaller classes, more teachers and a greater range of educational programs in all schools." Teachers may not know how to use smartphones to 'personalize instruction' according to students' needs because they lack experience of online teaching and the skill of designing online courses (Chun-lin, L. (2012). The second item that received a low rank by teachers was 'the possibility to create student-centred learning opportunities.' Over the past few years, several studies have proved that "teachers use technology to maintain their traditional teacher-centred practices or to enable their traditional instructional tasks, such as recording grades and creating databases" (Cuban, 2001, p. 179).

The third lowest-rated benefit was 'the ability to use existing instructional applications.' Almost half of the participants (53.4\%) either agreed or strongly agreed with this service. The implementation of existing smartphone applications is quite a difficult task for teachers due to a variety of factors. First, many educational applications are not designed by an educator (Orlando, 2017). Second, the high costs of software and further accessories are the main disadvantages of mobile-assisted learning (Perry, 2003). Third, the findings of studies suggest that most educational applications are not designed for EFL students. Also, the majority of applications are not designed for classroom (formal learning) use, but rather for self-study (informal learning) (Gimenez, JMagal-Royo, Garde, \& Prefasi, 2009). Additionally, a larger number of applications do not provide a space for interaction between students and their teachers (Mareš et al., 2015). Lastly, smartphone applications are not intended for a specific course of study, so they do not necessarily meet the needs of students (Zhang, Hung, \& Zhang, 2018).

The third question in the questionnaire asked the teachers about the primary drawbacks of utilizing smartphones for teaching vocabulary. Three of the drawbacks were found to have the highest percentage. $60.8 \%$ of the participants strongly agreed or agreed that 'poorly existing vocabulary teaching/learning applications might lead to misuse of vocabulary.' According to Teles and Tomimatsu (2014), the problem lies in the fact that most educational applications are low-quality applications, poorly designed and can frustrate learners and result in detrimental outcomes. The second highest-rated drawback was 'lack of training on smartphones for academic purposes.' 58.3\% of the teachers strongly agreed or agreed with this obstacle. Prior studies demonstrated that the biggest drawback that might inhibit the appropriate application of smartphones in the classroom is the 
lack of training on how to integrate mobile phones into the classroom (O'Bannon \& Thomas, 2015). The statement, 'smartphones can disrupt the instruction and distract students' was ranked third by the participants (51.7\%). There is agreement across a large number of studies that when smartphones are used in the classroom, they disrupt the smooth flow of the class by distracting students and making it difficult to maintain discipline (Santos, Bocheco, \& Habak, 2018).

With regard to the lowest-ranked statements with regards to disadvantages, the majority of respondents were least concerned about using 'smartphones for cheating.' Only $25.9 \%$ strongly agreed or agreed on this drawback. Although this result is incompatible with many prior studies, findings of a number of previous studies considered cheating a significant drawback to using smartphones in the classroom (Kibona \& Rugina, 2015; Buck, McInnis, \& Randolph, 2013). Campbell (2006) found that both students and teachers considered mobile devices ringing during class time as a source of distraction, however, they did not strongly consider mobile phones as a potential resource for cheating. Additionally, drawbacks such as 'the small-size screen' and 'the small-size keyboard' were not seen as barriers. To some extent, the screen size is no longer a problem as it was some years ago. Due to rapid advancements in technology at a breakneck pace, smartphone screens are now larger than previous screens and can display the contents on a single page that hitherto had to be split into multiple pages.

\section{Limitations and Future Research}

The researchers have identified two limitations to this study. These limitations may provide the impetus for future research into the same subject. The first limitation is that technology is inherently fast-paced and keeps changing at full tilt. It is assumed that in a matter of a few years, the mobile phone industry will have achieved upheavals in the technology, the specifications and capabilities of smartphones in such innovative ways that cannot even be predicted by the layman at present. The second limitation is that this study focused on the perception of EFL teachers in Saudi Arabia on the potential role of smartphones in helping students ameliorate their English lexical repertoire. This fact may put a damper on the generalizability of the findings of the current study. Similar research on the perception of EFL teachers in other parts of the world should bequeath to this area of research a more accurate understanding of the subject and a wider scope for generalizability.

\section{Conclusions}

The numbers of smartphone users globally have increased exponentially over the past few years. The majority of users use smartphones as a medium of social interaction. Therefore, smartphones have influenced every aspect of our lives today, whether in the street, at home, or in the classroom. Smartphones possess numerous functionalities that might facilitate language learning both inside and outside the classroom. The utilization of smartphones in educational contexts is certainly becoming more and more popular among EFL teachers. Since smartphones hold a considerable popularity in our everyday lives and their various effects can be obviously observed in many areas, teachers might be induced to create innovative smartphone-based methods to teach vocabulary. Under this framework, this study sought to explore teachers' perceptions of smartphones as a device for expediting English vocabulary learning.

A 27-item questionnaire was administered to 120 teachers in state and private schools in different cities in Saudi Arabia in order to obtain their conceptions. Particularly, the questionnaire presented 16 potential benefits and 11 drawbacks to using smartphones as a tool for teaching. Based on the first research question, findings revealed that teachers' perceptions of smartphones as a tool for vocabulary teaching were not influenced by gender, whereas perceptions differed in relation to years of teaching experience. Regarding the second research question, the benefits that obtained the greatest frequency of agreement appear to be ease of use of the smartphone, the ability to engage students anywhere and anytime, learning through game applications, and offering students a great deal of exposure to foreign language lexical items in context. For the third question, most of the teachers reported main drawbacks to use smartphones for teaching vocabulary, such as poorly existing vocabulary teaching/learning applications, lack of training on smartphones for academic purposes, and smartphones having the potential to disrupt instruction in the classroom and distract students.

Funding: This research received no external funding.

Acknowledgments: The authors would like to thank the administrations of the 47 schools for their cooperation with us. Many thanks are also due to all the tecahers who made the time and effort to respond to the survey.

Conflicts of Interest: The authors declare no conflict of interest. 


\section{References}

[1] Afzali, P., Shabani, S., Basir, Z., \& Ramazani, M. (2017). Mobile-assisted vocabulary learning: A review study. Advances in Language and Literary Studies, 8(2), 190-195. https://doi.org/10.7575/aiac.alls.v.8n.2p.190

[2] Agca, R. K., \& Özdemir, S. (2013). Foreign language vocabulary learning with mobile technologies. Procedia-Social and Behavioral Sciences, 83, 781-785. https://doi.org/10.1016/j.sbspro.2013.06.147

[3] Aljasir, S., Woodcock, A., \& Harrison, S. (2013). Facebook in Saudi Arabia: Some aspects of Facebook usage by Saudi university students. International Journal of Engineering and Technology, 5(1), 80. https://doi.org/10.7763/IJET.2013.V5.516

[4] Alkhoudary, Y. A. (2018). Utilizing Facebook in EFL writing classrooms in Oman. International Journal of Computing and Digital Systems, 7(4), 225232. https://doi.org/10.12785/ijcds/070406

[5] Al-Otaibi, H. M., AlAmer, R. A., \& Al-Khalifa, H. S. (2016). The next generation of language labs: Can mobiles help? A case study. Computers in Human Behavior, 59, 342-349. https://doi.org/10.1016/j.chb.2016.02.028

[6] Al-Said, K. M. (2015). Students' perceptions of Edmodo and mobile learning and their real barriers towards them. Turkish Online Journal of Educational Technology-TOJET, 14(2), 167-180.

[7] Alzahrani, H. (2016). Examining the effectiveness of utilizing mobile technology in vocabulary development for language learners. Arab World English Journal, 6(3), 108-119. https://doi.org/10.24093/awej/vol6no3.7

[8] Azabdaftari, B., \& Mozaheb, M. A. (2012). Comparing vocabulary learning of EFL learners by using two different strategies: Mobile learning vs. flashcards. The Eurocall Review, 20(2), 47-59. https://doi.org/10.4995/eurocall.2012.11377

[9] Barhoumi, C. (2015). The effectiveness of WhatsApp mobile learning activities guided by activity theory on students' knowledge management. Contemporary Educational Technology, 6(3), 221-238. https://doi.org/10.30935/cedtech/6151

[10] Bauer, A. L. (2002). Using computers in the classroom to support the English language arts standards. ERIC Number: ED465441, 465-441.

[11] Beck, D., \& Eno, J. (2012). Signature pedagogy: A literature review of social studies and technology research. Computers in the Schools, 29(1-2), 70-94. https://doi.org/10.1080/07380569.2012.658347

[12] Behbahani, A. R. (2016). A survey of university students' knowledge of vocabulary learning strategies and influential factors in Middle East. Journal of Language Teaching and Research, 7(4), 646-654. https://doi.org/10.17507/jltr.0704.03

[13] Bensalem, E. (2018). The impact of WhatsApp on EFL students' vocabulary learning. Arab World English Journal (AWEJ), 9(1), $23-38$. https://doi.org/10.24093/awej/vol9no1.2

[14] Buck, J. L., Mclnnis, E., \& Randolph, C. (2013). The new frontier of education: the impact of smartphone technology in the classroom. American Society for Engineering Education, 1(1), 1-11.

[15] Campbell, S. W. (2006). Perceptions of mobile phones in college classrooms: Ringing, cheating, and classroom policies. Communication Education, 55(3), 280-294. https://doi.org/10.1080/03634520600748573

[16] Chun-lin, L. (2012, July). Research on diffusion of network teaching platform innovations. In Computer Science \& Education (ICCSE), 2012 7th International Conference on (1855-1859). IEEE. https://doi.org/10.1109/ICCSE.2012.6295433

[17] Cuban, L. (2001). Oversold and underused: Reforming schools through technology, 1980-2000. Cambridge:Harvard University Press.

[18] Dimond, R., Bullock, A., Lovatt, J., \& Stacey, M. (2016). Mobile learning devices in the workplace: As much a part of the junior doctors' kit as a stethoscope? BMC medical education, 16(1), 207. https://doi.org/10.1186/s12909-016-0732-z

[19] Dunn, S. \& Ridgway, J. (1991). Computer use during primary school teaching practice: A survey. Journal of Computer Assisted Learning, 7, 7-17. https://doi.org/10.1111/j.1365-2729.1991.tb00220.x

[20] Ehrcke, T. A. (2013). 21st Century Learning Inc. Our Schools, Our Selves, 61-81.

[21] Ghosh, A., Jha, R., \& Malakar, S. K. (2016). Pattern of smartphone use among MBBS students in an Indian Medical College. International Journal of Advanced Research (IJAR), 2(5), 389-392.

[22] Gimenez, J. L., Magal-Royo T., Garde C. F., \& Prefasi, G. S. (2009). The adaptation of contents for the creation of foreign language learning exams for mobile devices. International Journal of Interactive Mobile Technologies (IJET), 3, 15-17. https://doi.org/10.3991/ijim.v3s1.1008

[23] Goh, S. Y. (2015). M-learning application for PT3 mathematics (Solid Geometry), (Unpublished Doctoral Dissertation). Universiti Tunku Abdul Rahman, Kampar, Perak, Malaysia.

[24] Gorham, R. (2010). Mobile Learning: Transforming the delivery of education and training. International Journal of E-Learning \& Distance Education, 24(3), 1-3. http://hdl.handle.net/10515/sy5057d59

[25] Goz, F., \& Ozcan, M. (2017). An entertaining mobile vocabulary learning application. The Eurasia Proceedings of Educational \& Social Sciences, 7 , 63-66.

[26] Hartnell-Young, E., \& Vetere, F. (2008). A means of personalizing learning: incorporating old and new literacies in the curriculum with mobile phones. Curriculum Journal, 19(4), 283-292. https://doi.org/10.1080/09585170802509872

[27] Hayati, A., Jalilifar, A., \& Mashhadi, A. (2013). Using short message service (SMS) to teach English idioms to EFL students. British Journal of Educational Technology, 44(1), 66-81. https://doi.org/10.1111/j.1467-8535.2011.01260.x

[28] Hu, Z. N. (2013). Emerging vocabulary learning: from a perspective of activities facilitated by mobile devices. English Language Teaching, 6(5), 4454. https://doi.org/10.5539/elt.v6n5p44

[29] Im, M. S. (2014). Students' perception of F2F TBLT and smartphones to enhance vocabulary retention. Korea TESOL Journal, $17(1), 87$.

[30] Jafari, S., \& Chalak, A. (2016). The role of WhatsApp in teaching vocabulary to Iranian EFL learners at junior high school. English Language Teaching, 9(8), 85-92. https://doi.org/10.5539/elt.v9n8p85

[31] Jin, S. H. (2014). Implementation of smartphone-based blended learning in an EFL undergraduate grammar course. The Korea Association of Multimedia-Assisted Language Learning, 17(4), 11-37. https://doi.org/10.15702/mall.2014.17.4.11

[32] Johns, K. (2015). Engaging and assessing students with technology: a review of Kahoot!. Delta Kappa Gamma Bulletin, 81(4), 89-91.

[33] Keengwe, J., \& Bhargava, M. (2014). Mobile learning and integration of mobile technologies in education. Education and Information Technologies, 19(4), 737-746. https://doi.org/10.1007/s10639-013-9250-3

[34] Kibona, L., \& Rugina, J. M. (2015). A review on the impact of smartphones on academic performance of students in higher learning institutions in Tanzania. Journal of Multidisciplinary Engineering Science and Technology, 2, 673-677. 
[35] Kyriacou, C., \& Zuin, A. (2016). Cyberbullying of teachers by students on YouTube: Challenging the image of teacher authority in the digital age. Research Papers in Education, 31(3), 255-273. https://doi.org/10.1080/02671522.2015.1037337

[36] Lakshmi, K. \&Nageswari, R. (2015). L2 learners' achievement in acquiring academic vocabulary in m-learning environment. The Modern Journal of Applied Linguistics, 1(7), 19-37.

[37] Lee, P. (2014, September). Are mobile devices more useful than conventional means as tools for learning vocabulary? In Embedded Multicore/Manycore SoCs (MCSoc), 2014 IEEE 8th International Symposium on (pp. 109-115). IEEE. https://doi.org/10.1109/MCSoC.2014.24

[38] Levy, M., \& Kennedy, C. (2005). Learning Italian via mobile SMS. Mobile learning: A handbook for educators and trainers, 1, 76-83.

[39] Lo, M. (2013). MathPen: Envisioning the future. Mathematics Teaching, 235, 19-21. https://eprints.soton.ac.uk/352437/2/MATHPEN.pdf

[40] Lu, M. (2008). Effectiveness of vocabulary learning via mobile phone. Journal of Computer Assisted Learning, 24(6) 515-525. https://doi.org/10.1111/j.1365-2729.2008.00289.x

[41] Mahajaroenkul, S. (2017). Informal learning strategies of international students seeking to learn English via mass and/or social media (Doctoral dissertation, Wichita State University).

[42] Maican, C. I., \& Cocoradă, E. (2017). Computers, Internet and smartphone attitudes among Romanian university students. European Journal of Multidisciplinary Studies, 5(1), 85-92. https://doi.org/10.26417/ejms.v5i1.p85-92

[43] Mareš, P., Holman, L., Sedláček, D., Šmejkal, P., Matějček, T., Štych, P., ... \& Šimková1, Z. (2015). Tablets in Science Education: Experience from Implementation in the Czech Republic. In Conference Proceedings. New Perspectives in Science Education (p. 159).

[44] McNeill, L., Rice, M. L., \& Wright, V. H. (2016, June). Advantages and barriers to using social media in online education. ANNUAL, 143-148.

[45] Medzini, A., Meishar-Tal, H., \& Sneh, Y. (2015). Use of mobile technologies as support tools for geography field trips. International Research in Geographical and Environmental Education, 24(1), 13-23. https://doi.org/10.1080/10382046.2014.967514

[46] Mlotshwa, Z., \& Giannakopoulos, A. P. (2015, September). The impact of mobile technology in education: A focus on business information systems at the International University of Management in Namibia. In International Conference on E-Learning, E-Education, and Online Training (pp. 76-83). Springer, Cham. https://doi.org/10.1007/978-3-319-28883-3 10

[47] Molina, A. I., Redondo, M. A., Lacave, C., \& Ortega, M. (2014). Assessing the effectiveness of new devices for accessing learning materials: An empirical analysis based on eye tracking and learner subjective perception. Computers in Human Behavior, 31, 475-490. https://doi.org/10.1016/j.chb.2013.04.022

[48] Muhammed, A. A. (2014). The impact of mobiles on language learning on the part of English foreign language (EFL) university students. ProcediaSocial and Behavioral Sciences, 136, 104-108. https://doi.org/10.1016/j.sbspro.2014.05.297

[49] Nikoopour, J., \& Kazemi, A. (2014). Vocabulary learning through digitized \& non-digitized flashcards delivery. Procedia-Social and Behavioral Sciences, 98, 1366-1373. https://doi.org/10.1016/j.sbspro.2014.03.554

[50] Norris, C., Hossain, A., \& Soloway, E. (2011). Using smartphones as essential tools for learning: A call to place schools on the right side of the 21st century. Educational Technology, 51(3) 18-25.

[51] O'Bannon B.W. \& Thomas K.M. (2015). Mobile phones in the classroom: preservice teachers answer the call. Computers \& Education, 85, $110-122$. https://doi.org/10.1016/j.compedu.2015.02.010

[52] O'bannon, B. W., \& Thomas, K. (2014). Teacher perceptions of using mobile phones in the classroom: Age matters! Computers \& Education, 74, 15-25. https://doi.org/10.1016/j.compedu.2014.01.006

[53] Orlando, J. (2017). Don't feel guilty about screen time for children. Western Sydney University, Australia.

[54] Patriana Ch, R., Irawan, I., Tampubolon, S., \& Pane, M. M. (2015). Benefits of using smartphones for improving students' learning outcomes at BINUS University. Advanced Science Letters, 21(7), 2396-2399. https://doi.org/10.1166/asl.2015.6288

[55] Pereira, S. G., \& Cadavieco, J. F. (2016). Approach to the phenomenon of m-learning in English teaching. Digital Education Review, (28), $19-36$.

[56] Perry, B. (2003). The use of pocket electronic dictionaries (PEDs) by Japanese university students. The Review of Liberal Arts, 105,165-176.

[57] Piccolo, L. S. G., Scharl, A., \& Baranauskas, C. (2012). Design of eco-feedback technology to motivate sustainable behavior: cultural aspects in a Brazilian context. In: International Conference on Information Resources Management, 21-23 May 2012, Vienna, Austria.

[58] Plackett, R., Thomas, S., \& Thomas, S. (2017). Professionals' views on the use of smartphone technology to support children and adolescents with memory impairment due to acquired brain injury. Disability and Rehabilitation: Assistive Technology, 12(3), 236-243. https://doi.org/10.3109/17483107.2015.1127436

[59] Popescu, A. I. (2011). Assessment of mobile learning contribution and practices in a lifelong learning society. International Journal of Arts \& Sciences, 4(8), 81-92.

[60] Rahimi, M., \& Yadollahi, S. (2011). Computer anxiety and ICT integration in English classes among Iranian EFL teachers. Procedia Computer Science, 3, 203-209. https://doi.org/10.1016/j.procs.2010.12.034

[61] Ravitz, J., Wong, Y., \& Becker, H. (1999). Report to participants. Teaching, Learning and Computing: 1998, A National Survey of Schools and Teachers.

[62] Reddy, E., Reddy, P., Sharma, B., Reddy, K., \& Khan, M. G. M. (2016, December). Student readiness and Perception to the use of smart phones for higher education in the pacific. In Computer Science and Engineering (APWC on CSE), 2016 3rd Asia-Pacific World Congress on (pp. 258-264). IEEE. https://doi.org/10.1109/APWC-on-CSE.2016.049

[63] Rico, M., Naranjo, M. J., Delicado, G., Plaza, N., \& Domínguez, E. (2014). Let's move: Mobile learning for motivation in language acquisition. Proceedings of the 7th ICT for Language Learning, Florence, Italy, 13-14.

[64] Rochman, M. (2010). The implementation of the 5E Model stages to build students' vocabulary. SKRIPSI Journal. http://karyailmiah.um.ac.id/index.php/PLS/article/view/6270

[65] Sandberg, J., Maris, M., \& Hoogendoorn, P. (2014). The added value of a gaming context and intelligent adaptation for a mobile learning application for vocabulary learning. Computers \& Education, 76, 119-130. https://doi.org/10.1016/j.compedu.2014.03.006

[66] Santos, I. M., Bocheco, O., \& Habak, C. (2018). A survey of student and instructor perceptions of personal mobile technology usage and policies for the classroom. Education and Information Technologies, 23(2), 617-632. https://doi.org/10.1007/s10639-017-9625-y

[67] Shelton, J. T., Elliott, E. M., Lynn, S. D., \& Exner, A. L. (2011). The distracting effects of a ringing cell phone: An investigation of the laboratory and the classroom setting. Journal of Environmental Psychology, 29(4), 513-521. https://doi.org/10.1016/j.jenvp.2009.03.001 
[68] Steel, C. (2012). Fitting learning into life: Language students' perspectives on benefits of using mobiles. Ascilite, 875-880.

[69] Stockwell, G. (2010). Using mobile phones for vocabulary activities: Examining the effect of platform. Language Learning \& Technology. 14(2), 95110.

[70] Stockwell, G., \& Hubbard, P. (2013). Some emerging principles for mobile-assisted language learning. The International Research Foundation for English Language Education, 1-15.

[71] Teles, S., Tomimatsu, K. (2014). Using cards as game mechanics to tach mathematics. International Journal of Asia Digital Art and Design. 18(2), 134-137.

[72] Thomas, K. M., O'Bannon, B. W., \& Britt, V. G. (2014). Standing in the schoolhouse door: Teacher perceptions of mobile phones in the classroom. Journal of Research on Technology in education, 46(4), 373-395. https://doi.org/10.1080/15391523.2014.925686

[73] Thorne, S. L., Black, R. W., \& Sykes, J. M. (2009). Second language use, socialization, and learning in Internet interest communities and online gaming. The modern language journal, 93, 802-821. https://doi.org/10.1111/j.1540-4781.2009.00974.x

[74] Turgay, H. \& Meriç G. (2017). Examining the perceptions of elementary level EFL university students regarding the use of smartphones in learning EFL vocabulary. Erzincan University Education Faculty Journal, 19(2), 19-36.

[75] Uberman, A. (1998). The use of games for vocabulary presentation and revision. Forum, 36 (1), 20.

[76] Wang, F. (2015). Constructivism-based mobile application for EFL vocabulary learning (Master's Degree). Suranaree University of Technology, Nakhon Ratchasima Province, Thailand.

[77] Wang, M., \& Shen, R. (2012). Message design for mobile learning: Learning theories, human cognition and design principles. British Journal of Educational Technology, 43(4), 561-575. https://doi.org/10.1111/j.1467-8535.2011.01214.x

[78] Wang, Y. H., \& Shih, S. K. H. (2015). Mobile-assisted language learning: effects on EFL vocabulary learning. International Journal of Mobile Communications, 13(4), 358-375. https://doi.org/10.1504/IJMC.2015.070060

[79] Wilkins, D. (1972). Linguistics in language teaching. Journal of the International Phonetic Association, 2(1), b1-b4.

[80] Woodcock, B., Middleton, A., \& Nortcliffe, A. (2012). Considering the smartphone learner: an investigation into student interest in the use of technology to enhance their learning. Student Engagement and Experience Journal, 1(1), 1-15. https://doi.org/10.7190/seej.v1i1.38

[81] $\mathrm{Wu}, \mathrm{Q}$. (2015). Designing a smartphone app to teach English (L2) vocabulary. Computers \& Education, 85, 170-179. https://doi.org/10.1016/j.compedu.2015.02.013

[82] Yaman, I., Şenel, M., \& Yeşilel, D. (2015). Exploring the extent to which ELT students utilize smartphones for language learning purposes. South African Journal of Education, 35(4). https://doi.org/10.15700/saje.v35n4a1198

[83] Yus, R., Bobed, C., Esteban, G., Bobillo, F., \& Mena, E. (2013). Android goes Semantic: DL Reasoners on Smartphones. Proceedings of the 2nd OWL Reasoner Evaluation Workshop (ORE 2013), 46-52.

[84] Zhang X., Hung SC., Zhang L. (2018) Designing Smart Apps to Enhance Learners' Engagement in Online Learning. In: Li K., Yuen K., Wong B. (eds) Innovations in Open and Flexible Education. Education Innovation Series. Springer. https://doi.org/10.1007/978-981-10-7995-5 11

[85] Zhu, Y., Hines, G. J., Burton, V., \& Liao, H. C. (2014). US Patent No. 8,660,573. Washington, DC: U.S. Patent and Trademark Office. 